Article

\title{
Two New Epoxysteroids from Helianthus tuberosus
}

\section{Xiao-Dong Li, Feng-Ping Miao and Nai-Yun Ji *}

Yantai Institute of Coastal Zone Research, Chinese Academy of Sciences, Yantai 264003, China; E-Mails: imnli@163.com (X.-D.L.); fpmiao@yic.ac.cn (F.-P.M.)

* Author to whom correspondence should be addressed; E-Mail: nyji@yic.ac.cn; Tel.: +86-535-2109176; Fax: +86-535-2109000.

Received: 5 September 2011; in revised form: 10 October 2011 / Accepted: 11 October 2011 / Published: 13 October 2011

\begin{abstract}
Two new epoxy steroids, $5 \alpha, 8 \alpha$-epidioxy-22 $\beta, 23 \beta$-epoxyergosta- 6 -en- $3 \beta$-ol (1) and $5 \alpha, 8 \alpha$-epidioxy-22 $\alpha, 23 \alpha$-epoxyergosta-6-en-3 $\beta$-ol (2), and ten known steroids

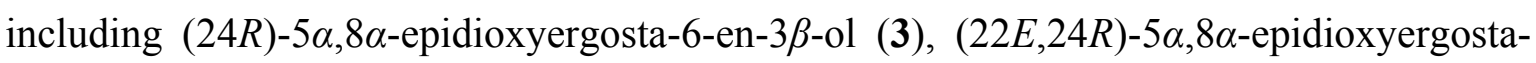
6,22-dien-3 $\beta$-ol (4), $\quad(22 E, 24 R)$-5 $\alpha, 8 \alpha$-epidioxyergosta-6,9(11),22-trien-3 $\beta$-ol (5), $\beta$-sitosterol (6), sitost-5-en-3 $\beta$-ol acetate (7), $7 \alpha$-hydroxysitosterol (8), schleicheol 2 (9), (24R)-24-ethyl-5 $\alpha$-cholestane-3 $\beta, 5 \alpha, 6 \beta$-triol (10), $7 \alpha$-hydroxystigmasterol (11), and stigmasterol (12) were isolated from Helianthus tuberosus grown in Laizhou salinized land of coastal zone of Bohai Sea, China. The structures of these compounds were unambiguously established by 1D, 2D NMR and mass spectroscopic techniques. The new compounds $\mathbf{1}$ and $\mathbf{2}$ exhibited weak antibacterial activity and no antifungal activity.
\end{abstract}

Keywords: Helianthus tuberosus; steroid; $5 \alpha, 8 \alpha$-epidioxy-22 $\beta, 23 \beta$-epoxyergosta-6-en- $3 \beta$-ol; $5 \alpha, 8 \alpha$-epidioxy-22 $\alpha, 23 \alpha$-epoxyergosta- 6 -en- $3 \beta$-ol

\section{Introduction}

Helianthus tuberosus Linn (Asteraceae, commonly named Jerusalem artichoke) is an herbaceous plant cultivated widely around the temperature areas for its edible tubers. In addition, it is widely used in industry as a raw material to produce inulin and ethanol [1,2]. Phytochemical investigations have indicated that this species is a rich source of sesquiterpenes and diterpenes [3,4]. Triterpenes and steroids have also been reported from this species [5,6]. Recently, H. tuberosus has been successfully planted in Laizhou salinized land for ameliorating the salizined soil, where the salt contents and $\mathrm{pH}$ 
values are $3.79 \mathrm{~g} / \mathrm{kg}$ and 7.55 at $0-20 \mathrm{~cm}$ depth and $4.01 \mathrm{~g} / \mathrm{kg}$ and 7.50 at $20-40 \mathrm{~cm}$ depth, respectively [7]. In order to explore the application of this grown plant, its secondary metabolites were examined. As a result, two new epoxysteroids, $5 \alpha, 8 \alpha$-epidioxy-22 $\beta, 23 \beta$-epoxyergosta-6-en-3 $\beta$-ol (1) and $5 \alpha, 8 \alpha$ epidioxy-22 $\alpha, 23 \alpha$-epoxyergosta-6-en-3 $\beta$-ol (2), and ten known steroids including (24R)-5 $\alpha, 8 \alpha$ epidioxyergosta-6-en-3 $\beta$-ol (3) [8], (22E,24R)-5 $\alpha, 8 \alpha$-epidioxyergosta-6,22-dien-3 $\beta$-ol (4) [9], (22E,24R)-5 $\alpha, 8 \alpha$-epidioxyergosta-6,9(11),22-trien-3 $\beta$-ol (5) [9], $\beta$-sitosterol (6) $[10,11]$, sitost-5-en-

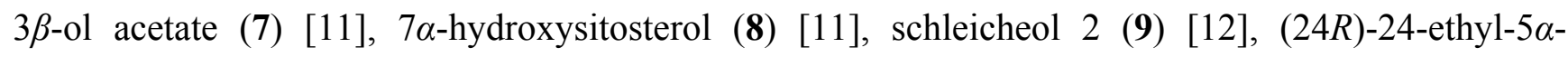
cholestane-3 $\beta, 5 \alpha, 6 \beta$-triol (10) [13], 7 $\alpha$-hydroxystigmasterol (11) [14], stigmasterol (12) [10] were isolated and identified (Figure 1). Herein we mainly report the isolation, structure elucidation, and bioactivity of steroids $\mathbf{1}-\mathbf{1 2}$.

Figure 1. Steroids 1-12 from H. tuberosus.
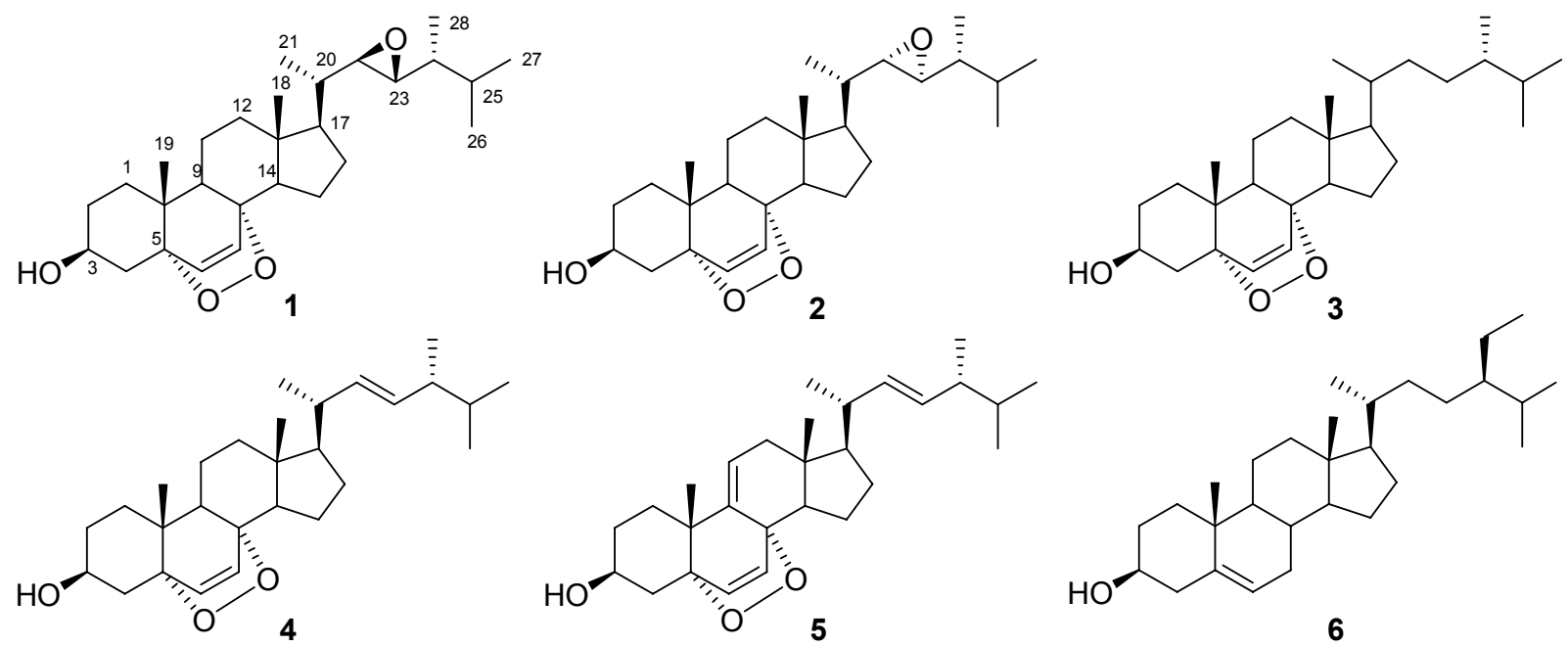

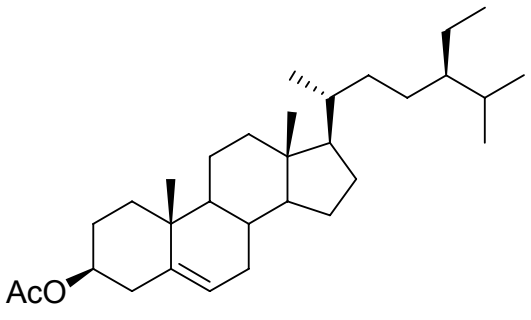

7

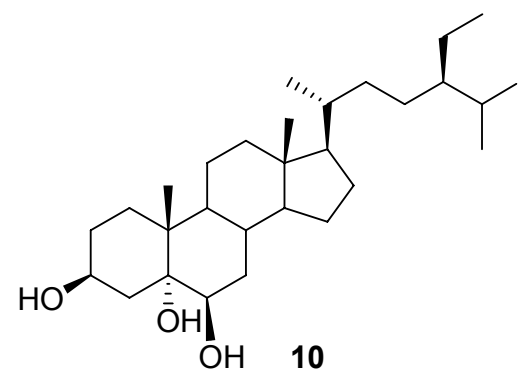

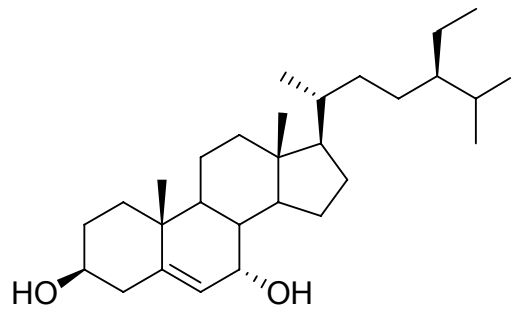

8

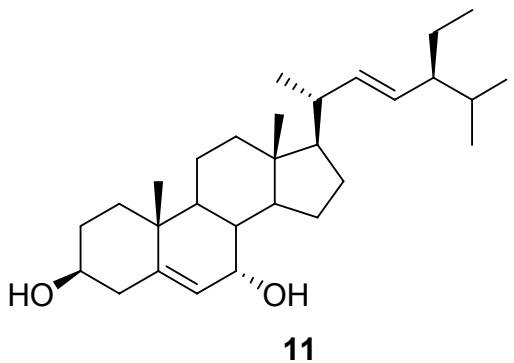

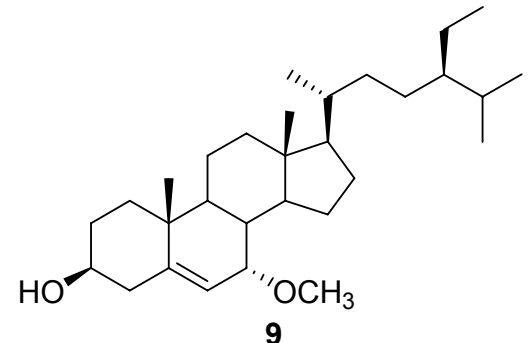

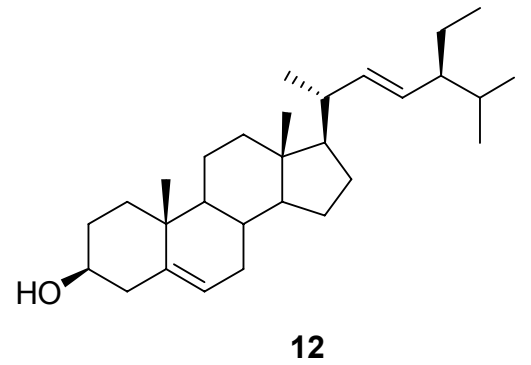

\section{Results and Discussion}

Compound 1 was obtained as a white solid. The broad IR absorption at $v_{\max } 3,410 \mathrm{~cm}^{-1}$ suggested the presence of a hydroxyl group in the molecule. The molecular formula was determined to be $\mathrm{C}_{28} \mathrm{H}_{44} \mathrm{O}_{4}$ on the basis of HREIMS $(\mathrm{m} / z \text { 444.3238 [M] }]^{+}$, calcd. for $\left.\mathrm{C}_{28} \mathrm{H}_{44} \mathrm{O}_{4}, 444.3240\right)$, indicating 
seven degrees of unsaturation. The ${ }^{1} \mathrm{H}-\mathrm{NMR}$ spectrum (Table 1) showed two methyl singlets, four methyl doublets, two double doublets assigned to two epoxygenated methines, one multiplet characteristic of an oxygenated methine, and two doublets attributed to two olefinic protons. The ${ }^{13} \mathrm{C}$ NMR and Distortionless Enhancement by Polarization Transfer (DEPT) spectra (Table 1) along with the HSQC experiment displayed the presence of six methyls, seven methylenes, eleven methines including one oxygenated methine (C-3), two epoxygenated methines (C-22 and C-23), and two $s p^{2}$ methines (C-6 and C-7), and four quaternary carbon atoms containing two oxygenated carbons (C-5 and C-8). Detailed NMR data comparison with those reported for (24R)-5 $\alpha, 8 \alpha$-epidioxyergosta-6-en$3 \beta$-ol (3) revealed that 1 differed from 3 mainly at the side chain moiety [8]. The $5 \alpha, 8 \alpha$-epidioxy moiety was further confirmed by the ${ }^{1} \mathrm{H}$ - and ${ }^{13} \mathrm{C}-\mathrm{NMR}$ data comparison with those of ergosta-6,22dien-3,5,8-triol and 5 $\beta, 8 \beta$-epidioxyergosta-6-en-3 $\beta$-ol [9,15]. Replacing two methylenes at C-22 and $\mathrm{C}-23$ in 3, two epoxy methines were located at C-22 and C-23 in $\mathbf{1}$ by the HMBC correlations from $\mathrm{H}-$ 21 to $\mathrm{C}-17$, C-20, and C-22, from $\mathrm{H}-22$ to C-20, from $\mathrm{H}-23$ to C-24, and from $\mathrm{H}-28$ to C-23, C-24, and $\mathrm{C}-25$ and ${ }^{1} \mathrm{H}-{ }^{1} \mathrm{H}$ COSY correlations between $\mathrm{H}-20 / \mathrm{H}-22, \mathrm{H}-22 / \mathrm{H}-23$, and $\mathrm{H}-23 / \mathrm{H}-24$. The relative configuration for the side chain moiety of $\mathbf{1}$ were established by the identical NMR data with those reported for $(22 R, 23 R, 24 R)$-24-methyl-22,23-epoxy-3 $\alpha, 5$-cyclo-5 $\alpha$-cholestan- $6 \beta$-yl acetate [16]. Furthermore, the NOESY correlation between $\mathrm{H}-20 / \mathrm{H}-23$ indicated C-20 and H-23 to be on the same side of the epoxy ring. The NOESY correlations of H-22 with $\mathrm{H}-17$ and H-21 allowed them to be the same orientation, while $\mathrm{H}-23$ and C-28 were assigned on the same face by the observed NOESY correlation between H-23/H-28. So, compound 1 was identified as $5 \alpha, 8 \alpha$-epidioxy-22 $\beta, 23 \beta$-epoxyergosta-6-en-3 $\beta$-ol, which was verified by the other HMBC, ${ }^{1} \mathrm{H}-{ }^{1} \mathrm{H}$ COSY (Figure 2), and NOESY correlations.

Compound 2 was also obtained as a white solid. The broad IR absorption at $v_{\max } 3,402 \mathrm{~cm}^{-1}$ indicated the presence of a hydroxyl group in the molecule. The molecular formula was also established to be $\mathrm{C}_{28} \mathrm{H}_{44} \mathrm{O}_{4}$ on the basis of HREIMS ( $\mathrm{m} / \mathrm{z} 444.3238$ [M] ${ }^{+}$, calcd. for $\mathrm{C}_{28} \mathrm{H}_{44} \mathrm{O}_{4}$, 444.3240), implying seven degrees of unsaturation. The ${ }^{1} \mathrm{H}-\mathrm{NMR}$ spectrum (Table 1) exhibited two methyl singlets, four methyl doublets, two double doublets representative of two epoxygenated methines, one multiplet ascribed to an oxygenated methine, and two doublets assignable to two olefinic protons. The ${ }^{13} \mathrm{C}-\mathrm{NMR}$ and DEPT spectra (Table 1) along with the HSQC experiment revealed the presence of six methyls, seven methylenes, eleven methines, and four quaternary carbon atoms. The NMR data showed close similarity to those of $\mathbf{1}$, with the exception of the different resonances for side chain moiety. The identical NMR data of the side chain moiety for 2 with those reported for (22S,23S,24R)-24-methyl-22,23-epoxy-3 $\alpha, 5$-cyclo-5 $\alpha$-cholestan-6 $\beta$-yl acetate and the observed HMBC and ${ }^{1} \mathrm{H}-{ }^{1} \mathrm{H}$ COSY correlations (Figure 2 ) confirmed 2 to be $5 \alpha, 8 \alpha$-epidioxy-22 $\alpha, 23 \alpha$-epoxyergosta-6en-3 $\beta$-ol, an isomer of $\mathbf{1}$ [16]. The observed NOESY correlations further confirmed the relative configuration for the side chain moiety. In the NOESY spectrum, the correlation between $\mathrm{H}-20 / \mathrm{H}-23$ located C-20 and H-23 on the same face of the epoxy ring. The correlations of H-22 with H-17 and $\mathrm{H}-21$ positioned them in the same direction, while $\mathrm{H}-23$ and C-28 were placed on the same side by the correlation between $\mathrm{H}-23 / \mathrm{H}-28$.

The antimicrobial activity of new epoxy steroids $\mathbf{1}$ and $\mathbf{2}$ were evaluated using a standard agar diffusion test at $30 \mu \mathrm{g} / \mathrm{disk}$. Compound $\mathbf{1}$ showed weak inhibitory activity against Escherichia coli and Staphylococcus aureus (inhibition diameter $7 \mathrm{~mm}$ ), and $\mathbf{2}$ exhibited weak inhibitory activity against 
E. coli (inhibition diameter $7 \mathrm{~mm}$ ). However, $\mathbf{1}$ and $\mathbf{2}$ were found no antifungal activity against plant pathogens Colletotrichum lagenarium and Fusarium oxysporium. Additionally, $\mathbf{1}$ and $\mathbf{2}$ exhibited inhibitory rates of $58.7 \%$ and $22.5 \%$, respectively, in the toxicity assay against brine shrimp (Artemia salina) at $100 \mu \mathrm{g} / \mathrm{mL}$.

Table 1. ${ }^{1} \mathrm{H}$ and ${ }^{13} \mathrm{C}$ NMR data for $\mathbf{1}$ and 2 (in $\mathrm{CDCl}_{3}, \delta$ in ppm, $J$ in $\mathrm{Hz}$ ).

\begin{tabular}{|c|c|c|c|c|}
\hline \multirow[t]{2}{*}{ No. } & \multicolumn{2}{|l|}{1} & \multicolumn{2}{|l|}{2} \\
\hline & $\delta_{\mathrm{H}}$ & $\delta_{\mathrm{C}}$ & $\delta_{\mathrm{H}}$ & $\delta_{\mathrm{C}}$ \\
\hline $1 \mathrm{a}$ & $1.70(\mathrm{~m})$ & $34.7\left(\mathrm{CH}_{2}\right)$ & $1.69(\mathrm{~m})$ & $34.7\left(\mathrm{CH}_{2}\right)$ \\
\hline $1 b$ & $1.95(\mathrm{~m})$ & & $1.95(\mathrm{~m})$ & \\
\hline $2 \mathrm{a}$ & $1.54(\mathrm{~m})$ & $30.1\left(\mathrm{CH}_{2}\right)$ & $1.55(\mathrm{~m})$ & $30.1\left(\mathrm{CH}_{2}\right)$ \\
\hline $2 b$ & $1.85(\mathrm{~m})$ & & $1.84(\mathrm{~m})$ & \\
\hline 3 & $3.97(\mathrm{~m})$ & $66.4(\mathrm{CH})$ & $3.97(\mathrm{~m})$ & $66.4(\mathrm{CH})$ \\
\hline $4 a$ & $1.91(\mathrm{~m})$ & $36.9\left(\mathrm{CH}_{2}\right)$ & $1.91(\mathrm{~m})$ & $36.9\left(\mathrm{CH}_{2}\right)$ \\
\hline $4 b$ & $2.12(\mathrm{ddd}, 13.8,4.9,1.4)$ & & $2.12(\mathrm{ddd}, 13.8,5.0,1.8)$ & \\
\hline 5 & & $82.2(\mathrm{C})$ & & $82.2(\mathrm{C})$ \\
\hline 6 & $6.26(\mathrm{~d}, 8.5)$ & $135.6(\mathrm{CH})$ & $6.25(\mathrm{~d}, 8.5)$ & $135.5(\mathrm{CH})$ \\
\hline 7 & $6.49(\mathrm{~d}, 8.5)$ & $130.5(\mathrm{CH})$ & $6.50(\mathrm{~d}, 8.5)$ & $130.6(\mathrm{CH})$ \\
\hline 8 & & $79.3(\mathrm{C})$ & & $79.4(\mathrm{C})$ \\
\hline 9 & $1.51(\mathrm{~m})$ & $51.1(\mathrm{CH})$ & $1.51(\mathrm{~m})$ & $51.2(\mathrm{CH})$ \\
\hline 10 & & $37.0(\mathrm{C})$ & & $37.0(\mathrm{C})$ \\
\hline $11 \mathrm{a}$ & $1.23(\mathrm{~m})$ & $23.4\left(\mathrm{CH}_{2}\right)$ & $1.24(\mathrm{~m})$ & $23.4\left(\mathrm{CH}_{2}\right)$ \\
\hline $11 b$ & $1.53(\mathrm{~m})$ & & $1.52(\mathrm{~m})$ & \\
\hline $12 \mathrm{a}$ & $1.28(\mathrm{~m})$ & $39.3\left(\mathrm{CH}_{2}\right)$ & $1.25(\mathrm{~m})$ & $39.4\left(\mathrm{CH}_{2}\right)$ \\
\hline $12 b$ & $1.98(\mathrm{~m})$ & & $1.93(\mathrm{~m})$ & \\
\hline 13 & & $45.0(\mathrm{C})$ & & $45.0(\mathrm{C})$ \\
\hline 14 & $1.57(\mathrm{~m})$ & $51.3(\mathrm{CH})$ & $1.57(\mathrm{~m})$ & $51.3(\mathrm{CH})$ \\
\hline $15 \mathrm{a}$ & $1.47(\mathrm{~m})$ & $21.0\left(\mathrm{CH}_{2}\right)$ & $1.48(\mathrm{~m})$ & $20.8\left(\mathrm{CH}_{2}\right)$ \\
\hline $15 b$ & $1.68(\mathrm{~m})$ & & $1.68(\mathrm{~m})$ & \\
\hline $16 \mathrm{a}$ & $1.43(\mathrm{~m})$ & $28.0\left(\mathrm{CH}_{2}\right)$ & $1.71(\mathrm{~m})$ & $27.1\left(\mathrm{CH}_{2}\right)$ \\
\hline $16 b$ & $1.96(\mathrm{~m})$ & & $2.01(\mathrm{~m})$ & \\
\hline 17 & $1.37(\mathrm{~m})$ & $53.9(\mathrm{CH})$ & $1.40(\mathrm{~m})$ & $56.3(\mathrm{CH})$ \\
\hline 18 & $0.79(\mathrm{~s})$ & $12.7\left(\mathrm{CH}_{3}\right)$ & $0.79(\mathrm{~s})$ & $12.8\left(\mathrm{CH}_{3}\right)$ \\
\hline 19 & $0.89(\mathrm{~s})$ & $18.2\left(\mathrm{CH}_{3}\right)$ & $0.88(\mathrm{~s})$ & $18.2\left(\mathrm{CH}_{3}\right)$ \\
\hline 20 & $1.17(\mathrm{~m})$ & $39.2(\mathrm{CH})$ & $1.31(\mathrm{~m})$ & $38.2(\mathrm{CH})$ \\
\hline 21 & $1.08(\mathrm{~d}, 6.4)$ & $16.9\left(\mathrm{CH}_{3}\right)$ & $0.99(\mathrm{~d}, 7.0)$ & $16.0\left(\mathrm{CH}_{3}\right)$ \\
\hline 22 & $2.38(\mathrm{dd}, 8.2,1.9)$ & $62.8(\mathrm{CH})$ & $2.58(\mathrm{dd}, 7.1,2.2)$ & $63.8(\mathrm{CH})$ \\
\hline 23 & $2.66(\mathrm{dd}, 8.4,1.9)$ & $63.9(\mathrm{CH})$ & $2.45(\mathrm{dd}, 7.8,2.2)$ & $60.3(\mathrm{CH})$ \\
\hline 24 & $1.09(\mathrm{~m})$ & $42.4(\mathrm{CH})$ & $1.05(\mathrm{~m})$ & $42.2(\mathrm{CH})$ \\
\hline 25 & $1.78(\mathrm{~m})$ & $31.0(\mathrm{CH})$ & $1.65(\mathrm{~m})$ & $31.1(\mathrm{CH})$ \\
\hline 26 & $0.92(\mathrm{~d}, 6.8)$ & $18.6\left(\mathrm{CH}_{3}\right)$ & $0.92(\mathrm{~d}, 6.8)$ & $19.5\left(\mathrm{CH}_{3}\right)$ \\
\hline 27 & $0.96(\mathrm{~d}, 6.8)$ & $20.2\left(\mathrm{CH}_{3}\right)$ & $0.95(\mathrm{~d}, 6.8)$ & $20.4\left(\mathrm{CH}_{3}\right)$ \\
\hline 28 & $0.91(\mathrm{~d}, 7.0)$ & $12.6\left(\mathrm{CH}_{3}\right)$ & $0.97(\mathrm{~d}, 6.9)$ & $13.6\left(\mathrm{CH}_{3}\right)$ \\
\hline
\end{tabular}


Figure 2. Key HMBC (curved arrows) and ${ }^{1} \mathrm{H}-{ }^{1} \mathrm{H}$ COSY (bold lines) correlations of $\mathbf{1}$ and 2.
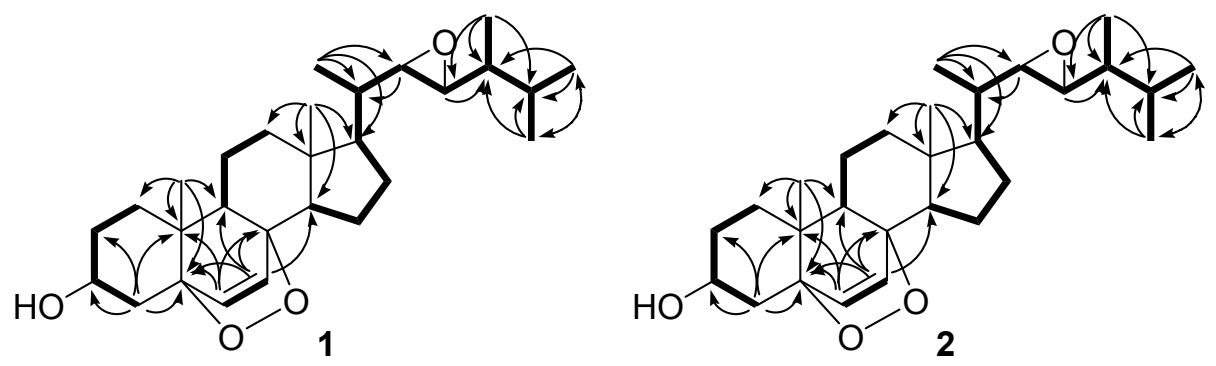

\section{Experimental}

\subsection{General}

NMR spectra were recorded at 500 and $125 \mathrm{MHz}$ for ${ }^{1} \mathrm{H}$ and ${ }^{13} \mathrm{C}$, respectively, on a Bruker Avance III $500 \mathrm{NMR}$ spectrometer in $\mathrm{CDCl}_{3}$ using TMS as internal standard. Low and high resolution mass spectra were determined on an Autospec Premier P776 mass spectrometer. IR spectra were obtained on a JASCO FT/IR-4100 Fourier Transform InfraRed spectrometer. HPLC separation was carried out on an Elite HPLC system (P270 pump, UV230+ detector, Dalian Elite Analytical Instruments Co., Ltd, Dalian, China) using an Eclipse XDB-C18 $(5 \mu \mathrm{m}, 9.4 \times 250 \mathrm{~mm})$ column. Column chromatography was performed with silica gel (100-200 and 200-300 mesh, Qingdao Haiyang Chemical Co., Qingdao, China) and Sephadex LH-20 (Pharmacia). Precoated silica gel plates (GF-254, Qingdao Haiyang Chemical Co., Qingdao, China) were used for preparative TLC purification. All solvents were of analytical grade.

\subsection{Plant Material}

Helianthus tuberosus Linn was grown by Qin-Tai Zhao in Laizhou salinized land of coastal zone of Bohai Sea, China, which was collected in December, 2008. A voucher specimen (SP0812) has been deposited at the Bio-Resource Laboratory of Yantai Institute of Coastal Zone Research, Chinese Academy of Sciences.

\subsection{Extraction and Isolation}

Extraction and isolation of the leaves: the dried and powdered sample $(1.1 \mathrm{~kg})$ was extracted exhaustively with $95 \%$ aqueous $\mathrm{EtOH}\left(5 \mathrm{~L}, 24 \mathrm{~h}, 25^{\circ} \mathrm{C}\right)$. The concentrated extract was partitioned between $\mathrm{H}_{2} \mathrm{O}$ and EtOAc. The EtOAc-soluble fraction $(19.1 \mathrm{~g})$ was subjected to silica gel column chromatography [CC, gradient of EtOAc in petroleum ether (PE) $(0-100 \%)$ ] to give nine fractions (Frs. I-IX), monitored by TLC. Fr. III eluted with PE/EtOAc (20:1) and was further purified by CC on silica gel (PE/EtOAc, 20:1) and Sephadex LH-20 $\left(\mathrm{CHCl}_{3} / \mathrm{MeOH}, 1: 1\right)$ and preparative TLC $\left(\mathrm{PE} / \mathrm{CHCl}_{3}, 3: 1\right)$ to yield 4 (16.6 mg) and 5 (3.1 mg). Fr. V eluted with PE/EtOAc (10:1) too and was further purified by $\mathrm{CC}$ on silica gel (PE/EtOAc, 9:1) and Sephadex LH-20 $\left(\mathrm{CHCl}_{3} / \mathrm{MeOH}, 1: 1\right)$ to afford $\mathbf{6}(13.5 \mathrm{mg}), \mathbf{1 2}(24.6 \mathrm{mg})$. Fr. VIII eluted with EtOAc and was further purified by CC on silica gel (PE/EtOAc, 1:1) and Sephadex LH-20 $\left(\mathrm{CHCl}_{3} / \mathrm{MeOH}, 1: 1\right)$ to give $8(4.5 \mathrm{mg})$ and a subfraction, which was further purified by preparative $\mathrm{HPLC}\left(\mathrm{MeOH} / \mathrm{H}_{2} \mathrm{O}, 4: 1\right)$ to yield $\mathbf{1 1}(3.7 \mathrm{mg})$. 
Extraction and isolation of the tubers: the dried and powdered sample $(16.0 \mathrm{~kg})$ was extracted with $95 \%$ aqueous EtOH $\left(50 \mathrm{~L}, 3 \mathrm{~d}, 25^{\circ} \mathrm{C}\right)$, then partitioned between $\mathrm{H}_{2} \mathrm{O}$ and EtOAc. The EtOAc-soluble fraction (53.0 g) was chromatographed over silica gel column using stepwise gradient of PE/EtOAc to yield twenty-six fractions (Frs. 1-26), based on TLC analysis. Fr. 6 eluted with PE/EtOAc (50:1) and was further purified by CC on Sephadex LH-20 $\left(\mathrm{CHCl}_{3} / \mathrm{MeOH}, 1: 1\right)$ and preparative TLC (PE/EtOAc, 40:1) to give 7 (11.2 mg). Fr. 12 eluted with PE/EtOAc (5:1) and was further purified by CC on silica gel (PE/EtOAc, 5:1) and preparative HPLC $\left(\mathrm{MeOH} / \mathrm{H}_{2} \mathrm{O}, 17: 3\right)$ to afford $6(1.8 \mathrm{mg}), 8(2.7 \mathrm{mg})$, 9 (1.5 mg), $12(7.5 \mathrm{mg})$, and a subfraction, which was further purified by preparative TLC $\left(\mathrm{CHCl}_{3} /\right.$ EtOAc, 3:1) to give $10(10.2 \mathrm{mg})$. Fr. 17 eluted with PE/EtOAc (2:1) and was purified by CC on silica gel (PE/EtOAc, 3:1) and Sephadex LH-20 $\left(\mathrm{CHCl}_{3} / \mathrm{MeOH}, 1: 1\right)$ and preparative HPLC $\left(\mathrm{MeOH} / \mathrm{H}_{2} \mathrm{O}, 3: 1\right)$ to yield $1\left(3.2 \mathrm{mg}, \mathrm{t}_{\mathrm{R}} 37 \mathrm{~min}\right), 2$ (3.3 $\left.\mathrm{mg}, \mathrm{t}_{\mathrm{R}} 41 \mathrm{~min}\right)$, and 3 (2.7 $\left.\mathrm{mg}, \mathrm{t}_{\mathrm{R}} 55 \mathrm{~min}\right)$.

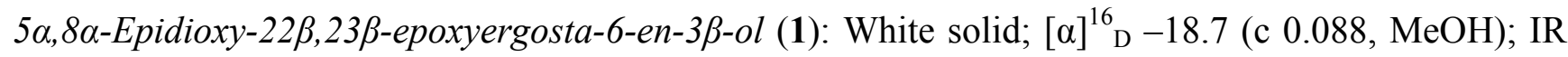
(KBr) $\mathrm{V}_{\max } 3410,2954,2881,1600,1462,1381,1041 \mathrm{~cm}^{-1} ;{ }^{1} \mathrm{H}-$ and ${ }^{13} \mathrm{C}-\mathrm{NMR}$ data, see Table 1;

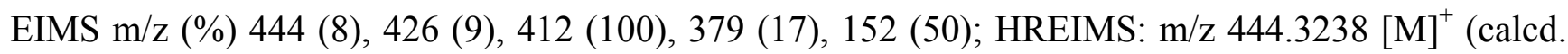
for $\mathrm{C}_{28} \mathrm{H}_{44} \mathrm{O}_{4}, 444.3240$ ).

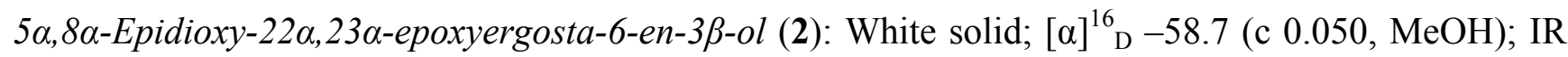
$(\mathrm{KBr}) \mathrm{V}_{\max } 3402,2954,2881,1624,1458,1381,1030 \mathrm{~cm}^{-1} ;{ }^{1} \mathrm{H}-$ and ${ }^{13} \mathrm{C}-\mathrm{NMR}$ data, see Table 1; EIMS m/z (\%) 444 (20), 426 (22), 412 (100), 379 (33), 268 (36), 152 (51); HREIMS: m/z 444.3238 $[\mathrm{M}]^{+}$(calcd. for $\mathrm{C}_{28} \mathrm{H}_{44} \mathrm{O}_{4}, 444.3240$ ).

\subsection{Bioassays}

Antibacterial and antifungal activities were assayed using chloramphenicol as positive control with inhibition diameters of 28 and $30 \mathrm{~mm}$ for E. coli and S. aureus, respectively, as described previously [17]. Toxicity against brine shrimp (Artemia salina) was also tested as described previously [18].

\section{Conclusions}

Enriched steroids with ergosterol (1-5), sitosterol (6-10), and stigmasterol $(\mathbf{1 1}, \mathbf{1 2})$ skeletons were isolated and identified from $H$. tuberosus planted in coastal salinized land, and ergosterol derivatives were reported from this species for the first time. The isolation of two new epoxy sterols $(\mathbf{1}, \mathbf{2})$ was a new addition to the molecular diversity of $H$. tuberosus, which exhibited weak antibacterial activity and toxicity against brine shrimp.

\section{Acknowledgments}

This work was financially supported by the Yantai Municipal Sci-Tech Development Program (2009164), Chinese Academy of Sciences for Key Topics in Innovation Engineering (KZCX2-YW225, KZCX2-YW-QN209), and Foundation of the Chinese Academy of Sciences for President's Scholarship (awarded to N.-Y. Ji). 


\section{References}

1 Baldini, M.; Danuso, F.; Turi, M.; Vannozzi, G.P. Evaluation of new clones of Jerusalem artichoke (Helianthus tuberosus L.) for inulin and sugar yield from stalks and tubers. Ind. Crop. Prod. 2004, 19, 25-40.

2 Szambelan, K.; Nowak, J.; Chrapkowska, K.J. Comparison of bacterial and yeast ethanol fermentation yield from Jerusalem artichoke (Helianthus tuberosus L.) tubers pulp and juices. Acta Sci. Pol. Technol. Aliment. 2004, 3, 45-53.

3 Pan, L.; Sinden, M.R.; Kennedy, A.H.; Chai, H.; Watson, L.E.; Graham, T.L.; Kinghorn, A.D. Bioactive constituents of Helianthus tuberosus (Jerusalem artichoke). Phytochem. Lett. 2009, 2, $15-18$.

4 Spring, O. Sesquiterpene lactones from Helianthus tuberosus. Phytochemistry 1991, 30, 519-522.

5 Chernenko, T.V.; Glushenkova, A.I.; Rakhimov, D.A. Lipids of Helianthus tuberosus tubers. Chem. Nat. Compd. 2008, 44, 1-2.

6 Uemura, M.; Yoshida, S. Studies on freezing injury in plant cells: II. protein and lipid changes in the plamsa membranes of Jerusalem artichoke tubers during a lethal freezing in vivo. Plant Physiol. 1986, 80, 187-195.

7 Xia, T.X.; Liu, Z.P.; Qi, C.H.; Chen, M.D. Effect of seawater irrigation on Helianthus tuberosus L. in Laizhou gulf. Agric. Res. Arid Areas 2004, 22, 60-63.

8 Gauvin, A.; Smadja, J.; Aknin, M.; Faure, R.; Gaydou, E.M. Isolation of bioactive $5 \alpha, 8 \alpha$-epidioxy sterols from the marine sponge Luffariella cf. variabilis. Can. J. Chem. 2000, 78, 986-992.

9 Greca, M.D.; Mangoni, L.; Molinaro, A.; Monaco, P.; Previtera, L. 5 $\beta, 8 \beta$-Epidioxyergosta-6,22dien-3 $\beta$-ol from Typha latifolia. Gazz. Chim. Ital. 1990, 120, 391-392.

10 Wright, J.L.C.; McInnes, A.G.; Shimizu, S.; Smith, D.G.; Walter, J.A.; Idler, D.; Khalil, W. Identification of C-24 alkyl epimers of marine sterols by ${ }^{13} \mathrm{C}$ nuclear magnetic resonance spectroscopy. Can. J. Chem. 1978, 56, 1898-1903.

11 Zhang, X.; Geoffroy, P.; Miesch, M.; Julien-David, D.; Raul, F.; Aoudé-Werner, D.; Marchioni, D. Gram-scale chromatographic purification of $\beta$-sitosterol, synthesis and characterization of $\beta$-sitosterol oxides. Steroids 2005, 70, 886-895.

12 Pettit, G.R.; Numata, A.; Cragg, G.M.; Herald, D.L.; Takada, T.; Iwamoto, C.; Riesen, R.; Schmidt, J.M.; Doubek, D.L.; Goswami, A. Isolation and structures of schleicherastatins 1-7 and schleicheols 1 and 2 from the teak forest medicinal tree Schleichera oleosa. J. Nat. Prod. 2000, $63,72-78$.

13 Notaro, G.; Piccialli, V.; Sica, D. $3 \beta, 5 \alpha, 8 \beta$-Trihydroxylated sterols with a saturated nucleus from two populations of the marine sponge Cliona copiosa. J. Nat. Prod. 1991, 54, 1570-1575.

14 Lu, W.G.; Zhang, J.; Su, J.Y.; Zeng, L.M. Stereo-synthesis and cholinesterase inhibitory activities of $\Delta^{5}-3 \beta, 7 \beta$-dihydroxy sterols and $\Delta^{5}-3 \beta, 7 \alpha$-dihydroxy sterols. Chin. J. Med. Chem. 2005, 15, 202-206.

15 Rivera, A.; Benavides, O.L.; Rios-Motta, J. (22E)-Ergosta-6,22-diene-3 $\beta, 5 \alpha, 8 \alpha$-triol: A new polyhydroxysterol isolated from Lentinus edodes (Shiitake). Nat. Prod. Res. 2009, 23, 293-300. 
16 Riccio, R.; Iorizzi, M.; Greco, O.S.; Minale, L.; Debray, M.; Menou, J.L. Starfish saponins, part 22. asterosaponins from the starfish Halityle regularis: a novel 22,23-epoxysteroidal glycoside sulfate. J. Nat. Prod. 1985, 48, 756-765.

17 Schulz, B.; Sucker, J.; Aust, H.J.; Krohn, K.; Ludewig, K.; Jones, P.G.; Döring, D. Biologically active secondary metabolites of endophytic Pezicula species. Mycol. Res. 1995, 99, 1007-1015.

18 Solis, P.N.; Wright, C.W.; Anderson, M.M.; Gupta, M.P.; Phillipson, J.D. A microwell cytotoxicity assay using Artemia salina (Brine shrimp). Planta Med. 1993, 59, 250-252.

Sample Availability: Samples of the compounds 1-12 are available from the authors.

(C) 2011 by the authors; licensee MDPI, Basel, Switzerland. This article is an open access article distributed under the terms and conditions of the Creative Commons Attribution license (http://creativecommons.org/licenses/by/3.0/). 